\title{
Claiming Human Dignity
}

\section{Citation}

Bobo, Lawrence D. 2010. Claiming human dignity. Du Bois Review: Social Science Research on Race 7(2): 253-255.

\section{Published Version}

doi:10.1017/S1742058X10000317

\section{Permanent link}

http://nrs.harvard.edu/urn-3:HUL.InstRepos:5241398

\section{Terms of Use}

This article was downloaded from Harvard University's DASH repository, and is made available under the terms and conditions applicable to Other Posted Material, as set forth at http:// nrs.harvard.edu/urn-3:HUL.InstRepos:dash.current.terms-of-use\#LAA

\section{Share Your Story}

The Harvard community has made this article openly available.

Please share how this access benefits you. Submit a story.

Accessibility 


\title{
CLAIMING HUMAN DIGNITY
}

\author{
Lawrence D. Bobo \\ Department of Sociology and of African and African American Studies, \\ Harvard University
}

In the concluding line of his opening note to Black Reconstruction in America, W. E. B. Du Bois, wrote "I am going to tell this story as though Negroes were ordinary human beings, realizing that this attitude will from the first seriously curtail my audience" (1934[2007], p. xliii). Doing so was an intellectually courageous step at the time Du Bois wrote. Jim Crow strictures, after all, were almost fully institutionalized across the South by that time and larger cultural motifs stressing redemption and reconciliation were steadily undoing the meager steps toward uplift and equality for African Americans of the Reconstruction era. Enormous progress notwithstanding, we know that great challenges of enduring inequality and persistent cultural racism remain in our time. The spirit of this declaration and the a priori intellectual posture it embraces have, quite fittingly then, animated this journal from our inception.

This theme of presuming the fundamental humanity of those too often objectified, stereotyped, stigmatized, and marginalized echoes throughout the pages of this issue of the Du Bois Review. We open with Henry Louis Gates Jr.'s interview with scholar and journalist Isabel Wilkerson discussing her major new book The Warmth of Other Suns: The Epic Story of America's Great Migration (2010). Wilkerson explains how she was drawn to the project and has brought into sharp relief the previously unappreciated extent to which the Great Migration simultaneously re-made Black America and the nation as a whole. In a fashion, what she does is to more fully write Blacks into the conventional American immigrant narrative. That is, Wilkerson excavates how in critical features the internal Black migration mirrored other more familiar immigrant streams in the core motivations, aspirations, and constraints that individuals and groups seeking "the warmth of other suns" endured and survived. Though these "immigrants" were Black and did not cross a national border, they unambiguously sought a better future for themselves and for their children; they endured rupture and loss of former homes and ties; they worked hard and sacrificed much in order to stake a meaningful claim for a share of that American dream.

Our "State of the Discipline" pieces can also be read as instances of human striving for the warmth of other suns in the presence of invidious racial distinction and inequality. Bryant Simon offers a provocative analysis of how the cultural motif of color-blindness is commodified by a corporate enterprise like Starbucks, making

Du Bois Review, 7:2 (2010) 253-255.

(C) 2010 W. E. B. Du Bois Institute for African and African American Research 1742-058X/10 \$15.00 doi:10.1017/S1742058X10000317 
their businesses and products, in part, vehicles for the performance of racial liberalism. In a world truly unfettered by racism, such performative outlets would be unnecessary. But in the current racial context, consuming Starbucks offers one relatively low-cost way for many Whites to assert innocence in the face of lingering problems of racial discrimination, segregation, and inequality.

The problem of the commodification of human strivings emerges in James Rosbrook-Thompson and Gary Armstrong's examination of Ghanaian soccer. They juxtapose Kwame Nkrumah's call for the development of a new "African Personality" in the post-colonial age and the on-going processes of economic subordination and resource extraction still characteristic of global north-global south relations. The theme of taking pride in a particular type of claim to personhood is, of course, a well-rehearsed idea in Black political leadership discourse (Shelby 2005). RosbrookThompson and Armstrong pivot off of Nkrumah's insistence that soccer would be one arena for asserting this new African Personality. They show how that sport remains embedded in an unequal global social order and thus falls well short of realizing Nkrumah's ambition.

Our "State of the Art" pieces take up, respectively, matters of who is embraced as members of the group and who has the resources to sustain a high standard of living. Mignon R. Moore takes up the challenges of Lesbian-Gay-Bisexual-Transgendered identity in the Black community. On the basis of rich new interview and ethnographic work in Los Angeles she explores the complexities of asserting both racial and sexuality-based identities. Her work highlights important generational differences within the LGBT community with regard to race- and sexuality-based identities as well as present day struggles to balance the two in a more holistic manner. In doing so, she not only brings to light the experiences of those typically suffering what political scientist Cathy Cohen (1999) has called "advanced marginalization," but makes us re-examine assumptions about the presumed fracturing of a broad Black sense of common fate identity (Dawson 1994; Gurin et al., 1989; Tate 1994). Shayla C. Nunnally examines the identity implications of growing ethnic diversity in the African American population. Using recently collected sample survey data she shows the distribution, strength (or lack thereof), and sources of a broad linking sense of common-fate identity in the light of growing number of Blacks with Caribbean, Latin America, or African backgrounds in the United States. Ngina Chiteji provides a careful mapping of contemporary wealth inequalities, in this instance focusing more on grandparents. This work shows not only the enormity of the remaining Black-White gaps in asset accumulation but shows how that gap is amplified across generations. If wealth is the more definitive material basis for sustaining a particular quality of life (Oliver and Shapiro 1995), then Chiteji is right to insist that in order to understand the face of current inequality it is not enough to consider parental inputs to a child's well-being, but those of potentially resource-rich grandparents also matter and must be considered.

The theme of claiming full humanity emerges with special force in the series of review essays on historian Robin Kelley's magisterial new biography of jazz great Thelonius Monk. Ingrid Monson, John Gennari, and Travis Jackson each bring a unique take to Thelonius Monk: The Life and Times of an American Original (2009). All three concur that Kelley's book is a major statement and remarkable scholarly work. Kelley places this often caricatured figure into fuller perspective, at once elevating Monk (e.g., he was no unschooled, primitive, instinctive musical genius), opening him to rightful criticism (e.g., arguably exploitative reliance on the women in his life), but most of all insisting on viewing Monk in the full complexity of the life and circumstances he made and lived through. 
Michael Jeffries offers us a broad gauge assessment and careful parsing of the first generation of "Obama Studies." Karen Kaufmann reviews a series of recent books on race and political attitudes and identities in the United States published immediately prior to the success of the Obama candidacy. And Clovis L. White takes stock of two recent major edited volumes, one interrogating the notion of race in all its facets and another focused on Black Los Angeles.

If there is a deep, unifying thread to these articles it is the on-going struggle of those on the dis-privileged side of the color line to claim full and simple humanity, unfettered, unmarked, uncompromised by assumptions about race. We trust these scholarly offerings, much like the warming sun of Isabel Wilkerson's book title, will provide further rays of much needed enlightenment.

\section{REFERENCES}

Cohen, Cathy (1999). The Boundaries of Blackness: AIDS and the Breakdown of Black Politics. Chicago, IL: University of Chicago Press.

Dawson, Michael C. (1994). Behind the Mule: Race, Class, and African American Politics. Princeton, NJ: Princeton University Press.

Du Bois, W. E. B. (1934[2007]). Black Reconstruction in America. New York: Oxford University Press.

Gurin, Patricia, Shirley Hatchett, and James S. Jackson (1989). Hope and Independence: Blacks' Response to Electoral and Party Politics. New York: Russell Sage Foundation.

Oliver, Melvin L. and Thomas M. Shapiro (1995). Black Wealth/White Wealth: A New Perspective on Racial Inequality. New York: Routledge.

Shelby, Tommie (2005). We Who Are Dark: The Philosophical Foundation of Black Solidarity. Cambridge, MA: Harvard University Press.

Tate, Kathrine (1994). From Protest to Politics: The New Black Voters in American Elections. Cambridge: Harvard University Press. 